unconscious material within a therapeutic setting can be examined and measured. Key moments within encounters of individuals in groups are not always as explicit as key events, such as the dance in our film. Key events may carry deeper meaning and possibility: the possibility of a homosexual experience between our two male characters through the external encounter with the scent of a woman seems remote if all we measure is the external visible manifestations.

Charlie reaches manhood through an encounter with death and madness. Part of Colonel Slade's plot includes his own suicide, but he reckons without his young friend, for Charlie proves both to himself and to Colonel Slade that he can experience madness and the threat of annihilation, and survive. The young man and the old man wrestle for the gun. In doing so they achieve an intimacy which allows Colonel Slade to 'see again' and gives Charlie his freedom.

The subject of this year's Cambridge conference was destruction. Within the contained environment of Queen's College, Old Hall, psychotherapists tried to grasp the meaning of destruction. It was through a realisation of a need to experience both internal and external madness that some light came. The destruction of the health service formed the back-cloth to the experience. Child abuse, marital breakdown and destruction of society were considered. Rivalry, envy and anger gave way to communion within the body of the conference and a realisation of man's capacity to procreate and live within the ruins.

The final scene in the film takes place in Charlie's school where he is 'on trial' for failing to tell on his school friends. In loco parentis Colonel Slade restores Charlie's lost sense of identification with father and with Charlie's vindication is finally able to relinquish him back to his old life. There has been a change however; Charlie has come of age and Colonel Slade has been able to move out of his pit of darkness, to live with his shadow because another could find beauty in his destructive madness. Of Klein's depressive position and Freud's view of the Oedipus complex, Meltzer has written, "It stands human values on its head looking backward at the relinquished object instead of forward to development and the possibility of an enriched object which the very relinquishment makes attainable". Keats' attempt was not to express "romantic agony" but to see death as "central to the experience of life and beauty" (Meltzer \& Williams, 1988).

Juliet Mitchell gave her views on the Cambridge conference papers and distilled the essence of the process from destructiveness to creativity. The therapeutic task, she felt, was to facilitate the transformation of nostalgia into history. The role of women in all of this seemed an ephemeral idea which rose up now and again like the waft of scent. Their guilt and destructiveness when they failed to protect their children was felt by the conference. The film showed us the guilt of the women in Charlie's courtroom as they presided over the destructive impulses of the headmaster. And yet it seemed that what was being addressed was not a sex difference but the union of animus and anima within an individual. Colonel Slade and Charlie danced the dance of the feminine and masculine. The task of the conferences was to bear both destructiveness and creativity; not to dwell in nostalgic ruins but to make history - and move on.

\section{Reference}

MELTZER, D. \& Williams M. H. (1988) The Apprehension of Beauty. The Role of Aesthetic Conflict in Development, Art and Violence. Scotland: Clunie Press.

\title{
A new look at Asylum
}

\section{J. H. M. CRIChTON, Nightingale Scholar and Honorary Registrar in Psychiatry, University of Cambridge Institute of Criminology, Cambridge CB3 9DT}

The 1970s horror film Asylum* is new out on the video store shelves. On the cover, above a severed head wrapped in brown paper, it warns, "you'll find more than cuckoos in this nest". This anthology of popular perceptions of madness and mad-doctors

*Asylum 1993 VIPCO videos. Director R. Ward Baker. Screenplay by Robert Bloch. was made some time ago and presents familiar stereotypes of mental illness. That it has been released on video now, in the wake of the Ashworth Inquiry and public concern over the mentally ill suggests that such stereotypes are enduring.

Robert Powell stars as an idealistic young psychiatrist, Dr Martin, who drives up through the storm to a dark imposing building, Dunsmoor 
Manor. The door is opened by a silent nurse in starched uniform. Martin has come about the SHO post and is shown down long polished corridors to the wheelchair-bound medical director. The medical director apologises for not standing and complains that he was crippled in a careless moment when his back was turned on a patient, who it turns out was the previous medical director, Dr Star. There follows a debate about whether the young doctor is up to the job:

"We're a long way from Harley Street out here; an Asylum for the incurably insane. You want to know the most useful thing here? This control system for the door upstairs. No keys, just an electrical device; the door cannot be opened from either side unless I press that button."

"If you're trying to warn me that some of the inmates are potentially dangerous you needn't worry. I've dealt with disturbed patients during my training."

"By what method?"

"Kindness ... understanding ... insight."

"Exactly my ways 20 years ago. Now I'm not so sure; those poor devils upstairs cannot be cured. They can only be confined and kept from being dangerous."

The scene is set, the patients are dangerous devils who, experience has shown, require control by an electrical device (like the ECT box?) able to open the door. As a test Martin is sent to try and identify the insane Dr Star. To Mussorgsky's 'Pictures at an Exhibition', Martin reviews some cases.

The door is unlocked by the congenial medical attendant to reveal the back of an attractive girl, singing nervously to herself. She had planned with her lover (Richard Todd) the murder of his wife. The wife had, however, just received a charm from a witch-doctor, which protected her to some degree since her body came back to life; unfortunately only after it had been quartered, with the bits wrapped in brown paper. The patient had been discovered trying to axe the brown-papered hand of the victim, which had clung to her face in revenge. Of course nothing of the lover or his partitioned wife was discovered, only the patient with wounds to her face.

The next patient is found to be pleasantly occupied with imagined sewing. The tailor (Barry Morse) speaks with an Eastern European accent and tells that he had been commissioned to make a magic suit, made from a multicoloured fabric, and the sinister client (Peter Cushing) instructed him to work only at night. After killing the client in an argument over payment, the tailor was attacked by his own dummy, brought to life by the magic suit.

The third patient seems very normal and is disappointed that Martin is not her lawyer. It turns out she has a friend no-one else can see (Britt Ekland), who has a contrasting personality to that of the patient. This apparent 'Mr Hyde' side of her had managed to murder her brother. The scene ends with the patient introducing her mirror reflection to Dr Martin as her friend. A clear case of schizophrenia in fiction.

The final case it seems must be the mad psychiatrist. Dr Byron (Herbert Lom) introduces himself as a maligned neurosurgeon and like Frankenstein he has created replicas of the human body, but in miniature. These dolls he is sure can, with the power of concentration, become alive.

Martin returns to report back with his findings and suggestions, but the director had already made up his mind - prefrontal lobotomy for Dr Byron! - and he slams a scalpel down on the desk. During this altercation the viewer sees one of the dolls come alive and make its way to the director's room. The viewer is unsure whether this is a fantasy of Dr Byron's or if it is perhaps the mad story of Martin and that he too is a patient retelling his own tale. The doll stabs the director and as the doll is grabbed by Martin and crushed beneath his feet a scream is heard from upstairs - Dr Byron is also crushed. Martin races upstairs and against the attendants' protests makes for the phone in the ward office. There he finds a strangled attendant; the helpful nurse who showed him around is the mad Dr Star who prepares to strangle Martin with a stethoscope.

These are trite tales packed with clichés and familiar themes from horror films. Yet this is a chilling reminder of popular images and fears. The maddoctors are no more sane than the madmen and all the patients are killers. The humane approach is in the end strangled. The asylum director is right about control and brain surgery and by allowing Martin in is killed off himself.

Enacted at the end of the story is a common fear. As a little doll runs amok, it even seems that the viewer has lost sanity - the risk a person runs by being too close to the insane. This film is a generation old but perhaps its message has found a new audience as public fears about the mentally ill in the community grow. How to address those fears is an altogether different story. 